\title{
PENGARUH LOAN TO DEPOSIT RATIO DAN DEBT TO EQUITY RATIO \\ TERHADAP RETURN ON ASSET \\ PADA PT BANK MANDIRI (PERSERO) TBK
}

Oleh:

\author{
ANDRI HELMI MUNAWAR, S.E., M.M. \\ Published: Jurnal Ilmiah Adbis Vol.2 No.2 Februari 2018. \\ ISSN: 2528-3928 \\ Dosen Program Studi Administrasi Bisnis \\ STISIP Bina Putera Banjar
}

Penelitian ini bertujuan untuk mengetahui dan menganalisis Loan to Deposit Ratio, Debt to Equity Ratio, Return on Asset dan pengaruh Loan to Deposit Ratio dan Debt to Equity Ratio terhadap Return on Asset pada PT Bank Mandiri (Persero) Tbk periode 2003-2014 baik secara simultan maupun parsial.

Metode yang digunakan dalam penelitian ini adalah metode deskriptif dan korelasional dengan menggunakan data sekunder. Analisis statistiknya menggunakan regresi berganda. Berdasarkan penelitian dapat disimpulkan bahwa secara simultan terdapat pengaruh tidak signifikan Loan to Deposit Ratio dan Debt to Equity Ratio terhadap Return On Asset pada PT Bank Mandiri (Persero) Tbk, secara parsial dapat disimpulkan bahwa terdapat pengaruh positif dan signifikan Loan to Deposit Ratio terhadap Return on Asset pada PT Bank Mandiri (Persero) Tbk, namun variabel Debt to Equity Ratio berpengaruh tidak signifikan terhadap Return On Asset pada PT Bank Mandiri (Persero) Tbk. Saran peneliti adalah berusaha menjaga nilai Loan to Deposit Ratio pada level yang optimal dengan tidak melebihi batas yang ditentukan, dengan besarnya debt sebaiknya bank tetap memperhatikan cost of fund dari setiap penghimpunan dana.

Kata Kunci: loan to deposit ratio, debt to equity ratio dan return on asset

\section{PENDAHULUAN}

Perusahaan keuangan ataupun non bank yang mengalokasikan dana pada sumber pendapatan alternatif, melalui pembelian saham atau obligasi pada instrumen keuangan asing, seperti Citigroup, UBS, Merril Lynch, Morgan Stanley, Lehman Brothers, Fannie Mae, Freddie Mac, American International Group (AIG) dan lainnya. Sedangkan dampak tidak langsung dari krisis adalah turunnya likuiditas, melonjaknya tingkat suku bunga, turunnya harga komoditas, melemahnya nilai tukar rupiah, dan melemahnya pertumbuhan sumber dana. Demikian juga, menurunnya tingkat kepercayaan konsumen, investor, dan pasar terhadap berbagai institusi keuangan yang menyebabkan melemahnya pasar modal.

Krisis keuangan global merupakan sumber instabilitas yang utama, hal ini karena perekonomian Indonesia semakin terintegrasi dengan perekonomian global. Selain itu, sumber dana dari luar negeri selama ini merupakan salah satu sumber 
dana yang penting, baik bagi perusahaan perbankan maupun perusahaan non perbankan. Oleh karena itu, krisis keuangan yang dialami sejumlah negara sejak beberapa waktu terakhir ini mempengaruhi kondisi keuangan Indonesia. Tidak saja sektor keuangan domestik menjadi semakin rentan oleh gejolak keuangan, perusahaan-perusahaan Indonesia menjadi semakin sulit mendapatkan dana asing untuk membiayai kegiatan usahanya. Akibatnya, perusahaan-perusahaan di sektor riil yang selama ini tergantung pada sumber pembiayaan dari luar negeri dapat terganggu kinerjanya dan dapat menurunkan debt repayment capacity dari perusahaan-perusahaan tersebut. Di perbankan, hal-hal ini dapat mendorong terjadinya peningkatan kredit bermasalah (NPL), serta perlambatan pertumbuhan kredit dan pembiayaan lainnya dalam valas yang dibutuhkan untuk mendukung kegiatan perekonomian. (http://www.cato.org/pubs/tbb/tbb_0109-52.pdf).

Tingkat kesehatan bank dapat dinilai dari beberapa indikator. Salah satu sumber utama indikator yang dijadikan dasar penilaian adalah laporan keuangan bank yang bersangkutan. Berdasarkan laporan itu akan dapat dihitung sejumlah rasio keuangan yang lazim dijadikan dasar penilaian tingkat kesehatan bank. Analisis rasio keuangan memungkinkan manajemen untuk mengidentifikasikan perubahan-perubahan pokok pada trend jumlah, dan hubungan serta alasan perubahan tersebut. Hasil analisis laporan keuangan akan membantu menginterpretasikan berbagai hubungan kunci serta kecenderungan yang dapat memberikan dasar pertimbangan mengenai potensi keberhasilan perusahaan di masa mendatang.

Masalah yang sering dihadapi bisnis perbankan adalah adanya persaingan tajam yang tidak seimbang yang dapat menimbulkan ketidakefisienan manajemen yang berakibat pada pendapatan dan munculnya kredit bermasalah yang dapat menimbulkan penurunan laba. Kredit bermasalah akan mempengaruhi permodalan yang juga dapat menyebabkan bank mengalami masalah likuiditas. Pertumbuhan kredit yang belum optimal tercermin dari angka-angka Loan to Deposit Ratio (LDR).

Tren pertumbuhan Dana Pihak Ketiga (DPK) akhir periode 2014 yang lambat dan pertumbuhan kredit yang senantiasa melewati $20 \%$ dalam lima tahun terakhir ini telah menaikkan angka Loan to Deposit Ratio (LDR) dari $72.88 \%$ di tahun 2009 menjadi 88.93\% di September 2014. Apabila tren LDR tinggi ini berlanjut maka ruang pertumbuhan kredit menjadi sangat terbatas, apalagi daya serap perbankan terhadap perekonomian (Produk Domestik Bruto/PDB) masih terbatas. Ketatnya likuiditas perbankan tentunya akan mempengaruhi peran perbankan dalam menjalankan fungsinya sebagai agen pembangunan, (http://ekonomi.kompasiana.com).

Berdasarkan fenomena tersebut di atas, likuiditas yang salah satu alat ukur penilaian kesehatannya dengan Loan to Deposit Ratio digunakan untuk melihat proporsi komposisi dana bank yang disalurkan maupun yang diterima. Selain likuiditas, solvabilitas perusahaan adalah salah satu alat ukur tingkat kesehatan bank, diantaranya untuk mengukur kemampuan bank menutup sebagian atau seluruh hutang-hutangnya dengan dana yang berasal dari modal sendiri digunakan Debt to Equity Ratio (DER). Dari segi profitabilitas untuk mengukur kemampuan manajemen bank dalam memperoleh keuntungan secara keseluruhan digunakan 
rasio Return on Asset. Setiap bank perlu mengawasi variabel-variabel tersebut agar tingkat kesehatannya terjamin.

Salah satu bank BUMN yang cenderung mengalami perubahan tingkat likuiditas, solvabilitas dan profitabilitas akibat perubahan perekonomian global adalah PT Bank Mandiri (Persero) Tbk. Secara singkat kinerja keuangan perusahaan tersebut dapat disajikan dalam tabel berikut ini:

\section{Tabel 1.1}

Loan to Deposit Ratio, Debt to Equity Ratio dan Return on Asset pada PT Bank Mandiri Tbk Periode 2012-2014

\begin{tabular}{|c|c|c|c|}
\hline Tahun & LDR & DER & ROA \\
\hline 2012 & $81,11 \%$ & $7,31 \%$ & $3,23 \%$ \\
\hline 2013 & $86,42 \%$ & $7,26 \%$ & $3,28 \%$ \\
\hline 2014 & $84,10 \%$ & $7,16 \%$ & $3,04 \%$ \\
\hline
\end{tabular}

Sumber: Laporan Keuangan PT Bank Mandiri Tbk (data diolah kembali, 2015)

Secara history, rasio Loan To Deposit Ratio (LDR) Bank Mandiri pada semester II-2014 cederung menurun dari $82,97 \%$ pada periode yang sama tahun lalu menjadi 82,02\%. Berdasarkan kondisi tersebut Bank Mandiri mampu menjaga tingkat likuiditas perusahaan dengan baik sehingga mampu mendukung rencana pengembangan bisnis perusahaan karena secara aturan BI, batas aman LDR suatu bank secara umum sekitar 85\%-100\% dengan batas maksimum LDR suatu bank 110\% (SE BI No.13/24/DPNP, 25 Oktober 2011). Komposisi utang terhadap modal sendiri atau dikenal dengan Debt to Equity Ratio dari tahun ke tahun cenderung mengalami penurunan. Tahun 2012 sebesar 7,31\%, tahun 2013 pada angka 7,26\% dan 2014 sebesar 7,16\%. Fluktuasi rasio-rasio tersebut, tentunya mempengaruhi posisi profitabilitas perusahaan.

Secara analisis, rasio Return On Asset PT Bank Mandiri Tbk selama 3 (tiga) tahun terakhir cenderung fluktuatif. Berdasarkan laporan keuangan hal ini disebabkan karena tingginya beban bunga tahun 2014 yang tidak diikuti kenaikan persentase total aktiva. Jika dikaitkan dengan kondisi fundamental tahun 2014, krisis keuangan mengurangi pasokan likuditas sektor keuangan karena bangkrutnya beberapa institusi keuangan global khususnya bank-bank investasi yang berpengaruh pada aliran kas perusahaan-perusahaan di Indonesia. Keadaan ini akan menyebabkan naiknya tingkat suku bunga dan turunnya pendanaan ke pasar modal dan perbankan global. Berdasarkan hal tersebut, ketatnya likuiditas perbankan juga menjadi salah satu faktor bank tidak tumbuh optimal, sehingga berdampak pada perolehan laba (infobank.com). Berdasarkan Tabel 1.1 di atas, jika dihubungkan dengan rasio LDR yang cenderung mengalami persentase kenaikan di 2013 dan mengalami penurunan di 2014 memungkinkan adanya korelasi dimana dengan turunnya angka LDR jumlah kredit yang disalurkan mengalami penurunan dibanding periode sebelumnya sehingga mengakibatkan laba operasi mengalami penurunan yang tentunya berpengaruh pada besarnya ROA. Selain itu penurunan DER yang menunjukkan posisi utang perusahaan selama 3 (tiga) tahun di atas mempengaruhi besarnya beban bunga yang dibayarkan dan besar kecilnya DER tentunya mempengaruhi posisi ROA perusahaan. Hal ini tentunya perlu penelitian 
lebih lanjut apakah Loan to Deposit Ratio dan Debt to Equity Ratio pada PT Bank Mandiri Tbk memiliki pengaruh terhadap Return on Asset?

\section{LANDASAN TEORI}

\section{Loan to Deposit Ratio (LDR)}

Dalam likuiditas terdapat dua risiko yaitu risiko ketika kelebihan dana dimana dana yang ada dalam bank banyak yang idle, hal ini akan menimbulkan pengorbanan tingkat bunga yang tinggi. Kedua risiko ketika kekurangan dana, akibatnya dana yang tersedia untuk mencukupi kebutuhan kewajiban jangka pendek tidak ada. Dan juga akan mendapat pinalti dari bank sentral. Kedua keadaan ini tidak diharapkan oleh bank karena akan mengganggu kinerja keuangan dan kepercayaan masyarkat terhadap bank tersebut. Jadi dapat disimpulkan bahwa ketika bank mengharapkan keuntungan yang maksimal akan berisikopada tingkat likuiditas yang rendah atau ketika likuiditas tinggi berarti tingkat keuntungan tidak maksimal, di sini terjadi konflik kepentingan antara mempertahankan likuiditas yang tinggi dan mencari keuntungan yang tinggi.

Pengeleloan likuiditas sangat penting bagi bank terutama untuk mengatasi risiko likuiditas yang disebabkan oleh dua hal diatas. Untuk menjaga agar risiko likuiditas ini tidak terjadi kebijakan manajemen likuiditas yang dapat dilakukan antara lain dengan menjaga asset jangka pendek.

Loan to Deposit Ratio (LDR) merupakan salah satu indikator pengukuran likuiditas. Pada dasarnya Loan to Deposit ratio (LDR) merupakan suatu pengukuran tradisional yang menunjukkan deposito berjangka, giro, tabungan, dan lain-lain yang digunakan dalam memenuhi permohonan pinjaman (loan requests) nasabahnya. Rasio ini digunakan untuk mengukur tingkat likuiditas. Rasio yang tinggi menunjukkan bahwasuatu bank meminjamkan seluruh dananya (loan-up) atau realtif tidak likuid (illiquid). Sebaliknya rasio yang rendah menunjukkan bank yang likuid dengan kelebihan kapasitas dana yang siap untuk dipinjamkan. Menurut Kasmir (2008: 232): Rasio LDR merupakan perbandingan antara total kredit yang diberikan dengan total Dana Pihak Ketiga (DPK) yang dapat dihimpun oleh bank. LDR akan menunjukkan tingkat kemampuan bank dalam menyalurkan dana pihak ketiga yang dihimpun oleh bank yang bersangkutan. CAR (Capital Adequacy Ratio) adalah rasio yang digunakan untuk mengukur permodalan cadangan penghapusan dalam menanggung perkreditan, terutama risiko yang terjadi karena bunga gagal ditagih.

Riyanto (2001: 25) tentang masalah likuiditas menyatakan bahwa: Masalah likuiditas adalah berhubungan dengan masalah kemampuan suatu perusahaan untuk memenuhi kewajiban finansialnya yang segera dipenuhi, jumlah alat-alat pembayaran (alat-alat) yang dimiliki oleh suatu perusahaan pada suatu saat tertentu merupakan kekuatan membayar dari perusahaan yang bersangkutan. Suatu perusahaan yang mempunyai kekuatan membayar belum tentu dapat memenuhi segala kewajiban finansialnya yang segera harus dipenuhi, atau dengan kata lain perusahaan tersebut belum tentu mempunyai kemampuan membayar (Zahoungskraft).

Likuiditas menunjukkan ketersediaan dana dan sumber dana bank pada saat ini dan masa yang akan datang. Pengaturan likuiditas bank terutama dimaksudkan 
agar bank setiap saat dapat memenuhi kewajiban-kewajiban yang harus segera dibayar. Bank wajib memelihara likuiditasnya yang didasarkan pada salah satu pengukurannya yaitu Loan to Deposit Ratio (LDR).

Menurut Kuncoro (2002: 285): "Loan to Deposit Ratio merupakan perbandingan jumlah pinjaman yang diberikan dengan simpanan masyarakat". Menurut Simorangkir (2004: 147): Loan to Deposit Ratio (LDR) adalah perbandingan antara kredit yang diberikan dan dana pihak ketiga, termasuk pinjaman yang diterima, tidak termasuk pinjaman subordinasi. Rasio ini menggambarkan kemampuan bank membayar kembali penarikan yang dilakukan nasabah deposan dengan mengandalkan kredit yang diberikan sebagai sumber likuiditasnya.

Rumus untuk mencari Loan to Deposit Ratio sebagai berikut:

$$
\text { Loan to Deposit Ratio }=\frac{\text { Kredit yang diberikan }}{\text { Dana pihak ketiga }} \times 100 \%
$$

Jumlah kredit yang diberikan dalam rumus di atas adalah kredit yang diberikan bank yang sudah direalisir atau ditarik atau dicairkan. Dana pihak ketiga meliputi simpanan masyarakat yang berupa giro, tabungan, dan berbagai jenis deposito.

\section{Debt to Equity Ratio (DER)}

Rasio solvabilitas atau rasio utang menunjukkan kemampuan perusahaan untuk memenuhi segala kewajiban finansiilnya apabila sekiranya perusahaan tersebut pada saat itu dilikuidasi, (Riyanto, 2001: 32). Pengukuran tingkat utang biasanya menggunakan debt ratio, debt to equity ratio. Semakin tinggi rasio ini maka semakin besar pula jumlah utang yang digunakan dalam operasi perusahaan.

Pada penelitian ini untuk pengukuran utang digunakan rasio utang (Debt to Equity ratio), karena merupakan rasio solvabilitas dimana rasio ini ditunjukan untuk mengadakan pengukuran sampai seberapa besar modal pinjaman (utang) perusahaan yang dibandingkan dengan total equity dalam membiayai aktivitas perusahaan,dan hasil pengukuran ini dinyatakan dalam persentase.

Menurut Sartono (2001: 121) menjelaskan:"Debt to Equity Ratio (DER) adalah total utang dibagi total modal sendiri yaitu dengan membandingkan antara total utang yang dimiliki perusahaan dengan modal sendiri."

Menurut Sutrisno (2003: 261) menjelaskan DER sebagai berikut: "DER adalah imbangan antara hutang yang dimiliki perusahaan dengan modal sendiri. Semakin tinggi rasio ini berarti modal sendiri semakin sedikit dibandingkan dengan hutangnya".

Menurut Dendawijaya, (2005: 121): "Debt to Equity Ratio adalah rasio yang digunakan untuk mengukur kemampuan perusahaan dalam menutup sebagian atau seluruh utang-utangnya, baik jangka panjang maupun jangka pendek, dengan dana yang berasal dari modal sendiri”. 
Rasio ini dapat dirumuskan sebagai berikut.

Debt to Equity Ratio $=\frac{\text { Jumlah Utang }}{\text { Jumlah Modal Sendiri }} \times 100 \%$

Dengan kata lain, rasio ini mengukur seberapa besar total pasiva yang terdiri atas persentase modal bank sendiri dibandingkan dengan besarnya utang. Semakin besar Debt to Equity Ratio (DER) suatu perusahaan menunjukkan semakin besarnya hutang perusahaan dibanding dengan modal sendiri yang dimiliki perusahaan. Penggunaan utang diharapkan akan menaikan tingkat pengembalian bagi pemegang saham.

Menurut Husnan (2004: 561): “Debt to Equity Ratio Rasio ini menunjukkan perbandingan antara hutang yang diberikan oleh para kreditur dengan jumlah modal sendiri yang diberikan oleh pemilik perusahaan".

Berikut ini adalah variabel-variabel pembentuk Debt to Equity Ratio, (Munawir, 2001: 273):

a. Utang adalah semua kewajiban keuangan perusahaan kepada pihak lain yang belum terpenuhi, dimana utang ini merupakan sumber dana atau modal perusahaan yang berasal dari kreditor. Utang dapat dibedakan ke dalam utang lancar dan utang jangka panjang.

1) Utang Lancar, adalah utang yang pelunasan atau pembayarannya akan dilakukan dalam jangka pendek (satu tahun sejak tanggal neraca) dengan menggunakan aktiva lancar yang dimiliki oleh perusahaan. Utang lancar meliputi:

1. Utang dagang

2. Utang wesel

3. Utang pajak

4. Biaya yang masih harus dibayar

5. Utang jangka panjang yang akan segera jatuh tempo

6. Penghasilan yang diterima di muka

2) Utang Jangka Panjang, adalah kewajiban keuangan yang jangka waktu pembayarannya (jatuh tempo) masih jangka panjang (lebih dari satu tahun sejak tanggal neraca). Utang jangka panjang meliputi:

a. Utang obligasi

b. Utang hipotik

c. Pinjaman jangka panjang yang lain.

b. Modal, modal adalah hak atau bagian yang dimiliki oleh perusahaan yang ditunjukkan dalam pos modal (modal saham), surplus dan laba yang ditahan. Modal suatu perusahaan dapat berupa modal saham bila untuk perseroan terbatas (PT) dan modal perseorangan untuk perusahaan perseorangan.

Dalam bisnis perbankan, sebagian besar dana yang ada pada suatu bank berasal dari simpanan masyarakat, baik berupa simpanan giro, tabungan ataupun deposito. Dengan demikian hanya sebagian kecil saja dana yang berasal dari modal sendiri. Selain memperoleh utang (kewajiban) dan deposan (penyimpan dana), 
bank juga memperoleh pinjaman dari lembaga-lembaga perbankan, baik dalam maupun luar negeri, serta pinjaman dari Bank Indonesia (KLBI, BLBI, dan fasilitas lain-lain).

\section{Return On Asset}

Perhitungan profitabilitas bank dalam penelitian ini adalah dengan menggunakan rasio Return On Asset (ROA). Menurut Sutrisno (2001: 238): "Return On Asset juga sering disebut rentabilitas ekonomis merupakan ukuran kemampuan perusahaan dalam menghasilkan laba dengan semua aktiva yang dimiliki oleh perusahaan. Dalam hal ini laba yang dihasilkan adalah laba sebelum bunga dan pajak atau EBIT."

Secara formulasi rumus ROA adalah:

$$
\text { Return On Asset }=\frac{\text { EBIT }}{\text { Total Aktiva }} \times 100 \%
$$

Menurut Horne dan Wachowicz (2005: 235), "ROA mengukur efektivitas keseluruhan dalam menghasilkan laba melalui aktiva yang tersedia; daya untuk menghasilkan laba dari modal yang diinvestasikan". Horne dan Wachowicz menghitung ROA dengan menggunakan rumus laba bersih setelah pajak dibagi dengan total aktiva, dimana kelebihan dan kelemahan Return on Assets sebagai berikut:

1) Kelebihan ROA diantaranya sebagai berikut:

a) ROA mudah dihitung dan dipahami.

b) Merupakan alat pengukur prestasi manajemen yang sensitif terhadap setiap pengaruh keadaan keuangan perusahaan.

c) Manajemen menitikberatkan perhatiannya pada perolehan laba yang maksimal.

d) Sebagai tolok ukur prestasi manajemen dalam memanfaatkan assets yang dimiliki perusahaan untuk memperoleh laba.

e) Mendorong tercapainya tujuan perusahaan.

f) Sebagai alat mengevaluasi atas penerapan kebijakan-kebijakan manajemen.

2) Di samping beberapa kelebihan ROA di atas, ROA juga mempunyai kelemahan di antaranya:

a. Kurang mendorong manajemen untuk menambah assets apabila nilai ROA yang diharapkan ternyata terlalu tinggi.

b. Manajemen cenderung fokus pada tujuan jangka pendek bukan pada tujuan jangka panjang, sehingga cenderung mengambil keputusan jangka pendek yang lebih menguntungkan tetapi berakibat negatif dalam jangka panjangnya.

Dalam analisis laporan keuangan, rasio ini paling sering disoroti, karena mampu menunjukkan keberhasilan perusahaan menghasilkan keuntungan. ROA mampu mengukur kemampuan perusahaan manghasilkan keuntungan pada masa 
lampau untuk kemudian diproyeksikan di masa yang akan datang. Assets atau aktiva yang dimaksud adalah keseluruhan harta perusahaan, yang diperoleh dari modal sendiri maupun dari modal asing yang telah diubah perusahaan menjadi aktiva-aktiva perusahaan yang digunakan untuk kelangsungan hidup perusahaan. Return On Asset juga sering disebut rentabilitas ekonomis merupakan ukuran kemampuan perusahaan dalam menghasilkan laba dengan semua aktiva yang dimiliki oleh perusahaan. Dalam hal ini laba yang dihasilkan adalah laba sebelum bunga dan pajak atau EBIT.

\section{OBJEK DAN METODE PENELITIAN}

Objek dalam penelitian ini adalah Loan to Deposit Ratio, Debt to Equity Ratio dan Return on Asset pada PT Bank Mandiri Tbk. Data yang diambil dalam penelitian ini adalah laporan keuangan Bank Mandiri periode 2003-2014. Penelitian dilakukan di Pojok Bursa Fakultas Ekonomi Universitas Siliwangi, Jalan Siliwangi No. 24 Tasikmalaya.

Metode yang digunakan dalam penelitian ini adalah metode deskriptif. Menurut Moh Nazir (2003: 54) mengemukakan metode deskriptif adalah suatu metode yang berusaha menyimpulkan, menyajikan serta menganalisis data sehingga dapat memberi gambaran yang cukup jelas mengenai objek yang diteliti dan menarik kesimpulan berdasarkan penelitian yang dilakukan. Tujuan dari deskriptif ini adalah membuat deskriptif secara otomatis, faktual, dan akurat mengenai fakta-fakta dan hubungan antara fenomena yang diselidiki.

\section{HASIL PENELITIAN}

Dari hasil penelitian, diperoleh data mengenai Loan to Deposit Ratio, Debt to Equity Ratio dan Return on Asset pada PT Bank Mandiri (Persero) Tbk periode 2003-2014 dihasilkan output data sebagai berikut:

Loan to Deposit Ratio, Debt to Equity Ratio dan Return on Asset PT Bank Mandiri (Persero) Tbk Periode 2003-2014

\begin{tabular}{|c|c|c|c|}
\hline Tahun & $\begin{array}{c}\text { LDR } \\
(\boldsymbol{\%})\end{array}$ & $\begin{array}{c}\text { DER } \\
(\boldsymbol{\%})\end{array}$ & $\begin{array}{c}\text { ROA } \\
(\mathbf{\%})\end{array}$ \\
\hline 2003 & 34,30 & 1123 & 2,82 \\
\hline 2004 & 44,95 & 895 & 3,03 \\
\hline 2005 & 44,10 & 1035 & 0,47 \\
\hline 2006 & 47,87 & 916 & 1,06 \\
\hline 2007 & 49,08 & 991 & 1,98 \\
\hline 2008 & 54,79 & 1075 & 2,25 \\
\hline 2009 & 55,91 & 1023 & 2,74 \\
\hline 2010 & 62,88 & 909 & 3,11 \\
\hline 2011 & 75,30 & 781 & 2,99 \\
\hline 2012 & 81,11 & 731 & 3,23 \\
\hline 2013 & 86,42 & 726 & 3,28 \\
\hline 2014 & 84,10 & 716 & 3,04 \\
\hline
\end{tabular}

Sumber: Pojok Bursa FE UNSIL (data diolah kembali) 


\section{A. Regresi Linier Berganda}

Setelah uji asumsi klasik dinyatakan layak baik uji normalitas, linearitas, multikolinearitas, heteroskedastisitas maupun autokorelasi maka selanjutnya adalah menguji hipotesis menggunakan teknik statistik. Untuk mengetahui persamaan regresi antar variabel dapat dijelaskan pada tabel Coefficient (data terlampir) dihasilkan persamaan regresinya:

$$
\mathrm{Y}=0,526+0,030 \mathrm{X} 1+0,019 \mathrm{X} 2
$$

Dari persamaan regresi tersebut dikatakan bahwa apabila Loan to Deposit Ratio dan Debt to Equity Ratio sama dengan nol (X =0) maka Return On Asset yaitu sebesar 0,526. Interpretasi dari masing-masing variabel yaitu sebagai berikut: a. Nilai X1 =0,030; jika Loan to Deposit Ratio pada PT Bank Mandiri (Persero) Tbk meningkat sebesar 100\% maka Return On Asset akan meningkat sebesar 0,030 atau 3\%. Artinya dengan semakin tingginya Loan to Deposit Ratio mencerminkan semakin besar proporsi pinjaman (kredit) terhadap jumlah simpanan masyarakat yang berdampak pada peningkatan Return On Asset.

b. Nilai X2 =0,019; jika Debt to Equity Ratio pada PT Bank Mandiri (Persero) Tbk meningkat (1 kali) maka Return On Asset akan meningkat sebesar 0,019 atau 1,9\%. Artinya kenaikan Debt to Equity Ratio akan meningkatkan Return On Asset pada PT Bank Mandiri (Persero) Tbk.

Berdasarkan analisis tersebut diketahui bahwa tinggi rendahnya Return On Asset ditentukan oleh Loan to Deposit Ratio dan Debt to Equity Ratio pada PT Bank Mandiri (Persero) Tbk, karena setiap perubahan Loan to Deposit Ratio maupun Debt to Equity Ratio akan mempengaruhi besar kecilnya Return On Asset.

\section{B. Koefisien Determinasi}

Koefisien determinasi digunakan untuk menentukan besarnya pengaruh antara variabel bebas terhadap variabel terikat. Nilai koefisien determinasi terletak diantara 0 dan 1 atau antara $0 \%$ sampai dengan 100\%, untuk mengetahui seberapa besar presentasenya dapat dilihat dari nilai $R$ square. Pada perhitungan koefisien determinasi dapat diketahui terlebih dahulu nilai korelasi $(\mathrm{R})$ yang digunakan sebelum mencari nilai koefisien determinasi. Untuk mengetahui besarnya pengaruh Loan to Deposit Ratio dan Debt to Equity Ratio terhadap Return on Asset pada PT Bank Mandiri (Persero) Tbk secara simultan, perhitungan dilakukan melalui program SPSS 20.0 for windows.

Berdasarkan hasil perhitungan pada tabel Model Summary (data terlampir) dapat diketahui bahwa $\mathrm{R}$ (koefisien korelasi) sebesar 0.558 dan untuk hasil koefisien determinasi untuk $\mathrm{R}$ Square $\left(\mathrm{R}^{2}\right)$ yaitu sebesar 0.311 , menunjukkan bahwa pengaruh antara variabel Loan to Deposit Ratio dan Debt to Equity Ratio secara bersama-sama terhadap Return on Asset pada PT Bank Mandiri (Persero) Tbk sebesar 31,10\%. Sisanya sebesar 68,90\% dipengaruhi oleh faktor-faktor lain selain Loan to Deposit Ratio dan Debt to Equity Ratio.

\section{Uji Hipotesis}

Untuk mengetahui ada tidaknya pengaruh secara bersama-sama variabel bebas terhadap variabel terikat dilakukan uji $F$ atau uji anova. Uji $F$ dapat dicari dengan membandingkan hasil dari tingkat signifikasi. Jika Sig > 0,05 maka Ho 
diterima dan jika Sig < 0,05 maka Ho ditolak. Pengujian dilakukan melalui program SPSS 20.0 for windows.

Diperoleh nilai signifikansi sebesar 0.187 Karena harga signifikansi lebih dari 0.05, atau nilai Sig. $0.187>\alpha(0,05)$, artinya Ho diterima dan Ha ditolak, maka dapat disimpulkan bahwa terdapat pengaruh tidak signifikan Loan to Deposit Ratio dan Debt to Equity Ratio terhadap Return On Asset pada PT Bank Mandiri (Persero) Tbk. Hal ini disebabkan karena perubahan atau naik turunnya Return On Asset tidak dipengaruhi sepenuhnya oleh Loan to Deposit Ratio dan Debt to Equity Ratio namun banyak variabel lain yang mempengaruhinya, diantaranya kebijakan perusahaan, tingkat suku bunga, persaingan, dan sebagainya.

Untuk mengetahui pengaruh Loan to Deposit Ratio terhadap Return on Asset pengujian dilakukan melalui program SPSS 20.0 for windows (data terlampir). Diperoleh tingkat signifikansi sebesar 0,040. Karena harga signifikansi kurang dari 0,05 , atau nilai Sig. $0,040<\alpha(0,05)$, artinya Ha diterima dan Ho ditolak, maka dapat disimpulkan bahwa terdapat pengaruh signifikan Loan to Deposit Ratio terhadap Return on Asset PT Bank Mandiri (Persero) Tbk.

Secara teoretis maupun secara analisis, bertitik tolak uraian tersebut dan dari hasil analisis pada dapat disimpulkan bahwa terdapat pengaruh positif dan signifikan Loan to Deposit Ratio terhadap Return on Asset pada PT Bank Mandiri (Persero) Tbk. Hal ini sesuai dengan penelitian terdahulu yang ditulis oleh Pandu Mahardian (2008) menyatakan bahwa secara parsial LDR berpengaruh positif dan signifikan terhadap ROA pada Perusahaan Perbankan yang Tercatat di BEJ periode Juni 2002-Juni 2007.

Loan to Deposit Ratio (LDR) merupakan bagian dari penilaian tingkat kesehatan bank yang merupakan rasio untuk mengukur komposisi jumlah kredit yang diberikan dibandingkan dengan jumlah dana masyarakat. Apabila bank sehat maka kemampuan bank dalam menciptakan laba akan bertambah. Faktor ekspansi kredit yang ditunjukkan dengan rasio LDR sangat penting oleh bank dalam menjalankan fungsi intermediasinya dengan tujuan untuk memperoleh laba yang diperoleh dari selisih penerimaan bunga kredit dengan bunga simpanan. Semakin tinggi rasio LDR semakin tinggi pula kemampuan bank dalam menyalurkan atau memberikan kredit sehingga kemampuannya dalam memperoleh laba akan meningkat (dengan asumsi berada di batas aman yang distandarkan yaitu 85-100\% dan tidak melebihi 110\%). Dengan demikian, melalui peningkatan dan pengelolaan penyaluran kredit yang baik akan mendorong suatu bank untuk meningkatkan kemampuannya dalam memperoleh laba (profitabilitas) yang salah satunya diukur dengan Return On Asset (ROA).

Untuk mengetahui pengaruh Debt to Equity Ratio terhadap Return on Asset pengujian dilakukan melalui program SPSS 20.0 for windows. Diperoleh tingkat signifikansi sebesar 0,107. Karena harga signifikansi lebih dari 0,05, atau nilai Sig. $0,107>\alpha(0,05)$, artinya Ho diterima dan Ha ditolak, maka dapat disimpulkan bahwa terdapat pengaruh tidak signifikan Debt to Equity Ratio terhadap Return on Asset PT Bank Mandiri (Persero) Tbk. Hal ini sesuai dengan penelitian terdahulu karya Suzka Puluala dan Eusia (2011) menyatakan bahwa secara parsial Debt to Equity Ratio (DER) berpengaruh tidak signifikan terhadap profitabilitas perusahaan Pada PT PG Rajawali II Cirebon Periode 2005-2009. Sesuai juga dengan penelitian 
karya Raditya Jatismara (2011) menyatakan bahwa secara parsial terdapat pengaruh DER terhadap ROA pada Perusahaan Manufaktur yang Listed di Bursa Efek Indonesia Periode Tahun 2008-2010.

Secara teoretis maupun secara analisis, bertitik tolak uraian tersebut dan dari hasil analisis dapat disimpulkan bahwa terdapat pengaruh secara parsial Debt to Equity Ratio terhadap Return on Asset pada PT Bank Mandiri (Persero) Tbk. Debt to Equity Ratio (DER) mengukur seberapa besar total pasiva yang terdiri atas persentase modal bank sendiri dibandingkan dengan besarnya utang. Pengaruh jumlah utang bank yang sebagian besar adalah dana dari simpanan masyarakat baik berupa giro, tabungan dan deposito dengan modal sendiri bank akan berpengaruh terhadap kondisi profitabilitas atau dalam hal ini Return On Asset. Jika DER semakin tinggi, maka kemampuan perusahaan untuk mendapatkan profitabilitas akan semakin rendah. DER yang tinggi menunjukkan semakin besarnya modal pinjaman yang digunakan untuk pembiayaan aktiva perusahaan. DER sekaligus menunjukkan struktur modal yang digunakan oleh perusahaan. Perusahaan dengan laba bertumbuh, akan memperkuat hubungan antara DER dengan profitabilitas yaitu dimana profitabilitas akan meningkat seiring dengan DER yang rendah.

\section{DAFTAR PUSTAKA}

Agus Sartono. 2001. Manajemen Keuangan. Yogyakarta: BPFE Yogyakarta.

Bambang Riyanto. 2001. Dasar-dasar Pembelanjaan Perusahaan. Yogyakarta: BPFE.

Brigham \& Houston, 2004. Dasar-dasar Manajemen Keuangan. Jakarta: Salemba Empat.

Horne dan Wachowicz. 2005. Fundamentals of Financial: Management PrinsipPrinsip Manajemen Keuangan. Penerjemah: Dewi Fitriasari dan Deny Arnos Kwary. Jakarta: Salemba Empat.

Kasmir. 2008. Bank dan Lembaga Keuangan Lainnya. Jakarta: PT RajaGrafindo.

Kuncoro. 2002. Metode Penelitian Kuantitatif. Yogyakarta : UPP AMP YKPM.

Lukman Dendawijaya. 2005. Manajemen Perbankan, Edisi kedua. Jakarta: Ghalia Indonesia.

Malayu Hasibuan. 2002. Dasar-Dasar Perbankan. Jakarta: PT Bumi Aksara.

Mamduh Hanafi. 2004. Manajemen Keuangan. Yogyakarta: BPFE.

Munawir, 2001. Analisis Laporan Keuangan, Edisi Ke-4.Yogyakarta: Liberty.

Moh Nazir. 2003. Metode Penelitian Bisnis. Jakarta: Ghalia Indonesia.

Nur Supomo Indriantoro. 2007. Metodologi Penelitian Bisnis. Yogyakarta: BPFE-Yogyakarta.

Simorangkir. 2004. Pengantar Lembaga Keuangan Bank dan Nonbank. Jakarta: Ghalia Indonesia.

Sofyan Safri Harahap. 2004. Analisis Kritis Atas Laporan Keuangan. Jakarta: RajaGrafindo Persada.

Suad Husnan. 2004. Manajemen Keuangan Edisi empat. Yogyakarta: BPFE.

Sutrisno. 2003. Manajemen Keuangan Teori, Konsep, dan Aplikasi. Yogyakarta: EKONISIA. 
2005. Manajemen Keuangan Teori, Konsep, dan Aplikasi. Yogyakarta : EKONISIA.

Wild, John J. Subramanyam, K.r. Halsey, Robert F. 2005. Analisis Laporan Keuangan. Buku 1. Ed. 8, Jakarta: Salemba Empat. Penerjemah: Yanivi S. Bactiar dan S. Nurwahyu harahap.

\section{SUMBER LAIN:}

Ni Kadek Venimas Citra Dewi, Wayan Cipta dan I Ketut Kirya. 2015. Jurnal: Pengaruh LDR, LAR, DER dan CR Terhadap ROA pada Bank yang Listing di BEI.

Pandu Mahardian. 2008. Jurnal: pengaruh Capital Adequacy Ratio (CAR), Efisiensi Operasi (BOPO), Non Performing Loan (NPL), Net Interest Margin (NIM), dan Loan to Deposit Ratio (LDR) terhadap Return on Asset (ROA) sebagai proksi dari Kinerja Keuangan Perusahaan Perbankan yang Tercatat di BEJ periode Juni 2002 hingga Juni 2007

Rangga Yudistia. 2009. Jurnal: Pengaruh Loan to Deposit Ratio dan Debt to Equity Ratio terhadap Return on Asset pada bank-bank yang tercatat di BEI.

Surat Edaran Bank Indonesia No.13/24/DPNP tanggal 25 Oktober 2011 perihal tata cara penilaian tingkat kesehatan bank umum

Undang-undang No.10 Tahun 1998 Tentang Perbankan. 